\title{
STUDY OF VERTICAL MOVEMENTS OF THE EUROPEAN CRUST USING TIDE GAUGE AND GNSS OBSERVATIONS
}

\author{
Kornyliy Tretyak, Solomiya Dosyn \\ Institute of Geodesy \\ National University Lviv Polytechnic \\ Lviv, Ukraine
}

\begin{abstract}
This research is devoted to the study of vertical movements of the European crust on the basis of two independent methods, namely tide gauge and GNSS observations results. The description and classification of factors affecting sea level change has been made. The precision with which the movement of the earth's crust according to the results of tide gauge observations can be explored has been calculated. A methodology to identify the duration of tide gauge observations required for studies of vertical movements of the earth's crust has been presented. Approximation of tide gauge time series with the help of Fourier series has been implemented, the need for long-term observations in certain areas has been explained. The diagram of the velocities of the vertical movements of the European crust on the basis of the tide gauge data and GNSS observations has been built and the anomalous areas where the observations do not coincide have been identified.
\end{abstract}

Keywords: vertical land movement, tide gauge, GNSS observations, sea level change

\section{Introduction}

Information about slow movements of the earth's crust (especially in tectonically unstable areas) is becoming more and more necessary when creating the reference geodetic networks, the design of large long-term facilities - ports, canals, hydroelectric power stations.

Today there are different methods of observation of the movements of the earth's crust; in particular, it is explored by the use of geodetic, geophysical, oceanographic and geomorphological methods.

The advent of GNSS stations provided an opportunity to study these movements with relatively high accuracy. Their spatial distribution allows monitoring at global and 
local scales. Permanent observations with the use of tide gauge and depth-gauge allow reliably assess changes in sea levels and movements of the coastline of the continents.

The peculiarity and complexity of these researches is that the tide gauges' results that record sea level (relative) contain two components: oceanographic (associated with changes in the ocean) and vertical component of the movement of the earth's crust (because the devices themselves are situated on land). Tide gauges record vertical offset of the item as a change in the gravitational field of the Earth and as the spatial deformation of the earth's crust, and GNSS-receivers - as spatial deformation of the earth's crust.

There are several techniques to study the vertical movements of the earth's crust on the basis of data from sea level. Bouin \& Wöppelmann (2010), in order to determine the vertical movement of the world's coastline, from the mean value of absolute global sea levels rise in the $X X$ century, which is $1.8 \pm 0.5 \mathrm{~mm} / \mathrm{yr}$ (Bindoff et al., 2007), subtracted the values of the relative trends in sea level, obtained from the tide gauges' records. A value of $1.8 \pm 0.5 \mathrm{~mm} / \mathrm{yr}$ is obtained by averaging the tide gauges' records that are located along the world's coastlines. But it should be remembered that there are regions where the trends exceed the global mean sea level in 10 times (e.g., in the Western Pacific and Eastern Indian oceans). Therefore, this approach to the determination of the vertical movements of the crust is not fully justified.

The same technique was used Bingley et al. (2001) in the study of vertical movements of the Great Britain's crust, but the value of global mean sea level rise is considered equal to $1.5 \mathrm{~mm} / \mathrm{yr}$.

Another method (Zervas et al., 2013) of study of the vertical movements of the earth's crust applies accounting oceanic "residuals" and individual seasonal cycle of the stations. Still others include a comparison of satellite altimetry data with concurrent tide gauges' data changes (Nerem \& Mitchum, 2002), (Kuo et al., 2004). But the results of altimetry measurements are affected by decadal variations in sea level (such as, e.g., Pacific Decadal Oscillation). So, to avoid this, we need longer time series. Another technique is the use of repeated static GNSS measurements of the datum level on the tide gauge within a certain period of time.

Santamaría-Gómez et al. (2014) proposed a new approach for the accurate determination of long-term vertical land movements. It is to determine doubledifferences of the long-term tide gauge records and short data of satellite altimetry. This approach eliminates the use of the absolute value of sea level rise, and thanks to the double subtraction of altimetric rates the authors managed to avoid minor errors in satellite altimetry such as orbital and sea surface pressure errors and altimeter drift.

Our goal is to identify the vertical movements of the crust of the European coastal areas on the basis of tide gauge and GNSS observations. The question of the precision with which one can determine the movement of the earth's crust according to the results of tide gauge observations will be considered, as well as the minimum duration of tide gauge observations required to achieve this precision. One of the criteria that will serve as a basis to believe that sea level change reflects the vertical movements of the earth's crust is the concordance of tide gauge results and GNSS observations. 


\subsection{Classification of factors affecting sea level change}

The sea level observations are carried out with the use of tide gauge and satellites (altimetry).

Unlike the network of coastal tide gauges, results from satellite altimetry provide almost global and homogeneous data level of the oceans, they are used due to the mass of the data set and averaging. The density of measurements is very high, which provides the ability to conduct a variety of studies, but the duration (about 20 years) is insufficient for the study of long-period changes in sea level.

Tide gauges perform high accuracy measurements of the instantaneous position of sea level. But to study the vertical movements of the crust long-term time series observations are needed. The accuracy of determining trends of average sea level using tide gauge observations depends on their duration. The results of single measurements of satellite altimetry provide an order of magnitude (or two orders of magnitude) lower accuracy. But eventually, thanks to the mass observation and duration of satellite altimetry measurements, the accuracy of determining the average trend level is almost identical with the results of tide gauge observations (Wahl et al., 2013).

A variety of endogenous and exogenous factors have an impact on the water surface, and therefore on the results of both types of observations. They have different nature, the nature of the action (random or systematic), and time scale (from a few seconds to millions of years). In particular, the sea level observations usually show significant regional variations due to the geodynamic processes and changes in oceanic and atmospheric circulation.

The largest contributions to sea level rise make the thermal expansion due to warming of the oceans and loss of ice volume, located on the land (the melting of glaciers, ice sheets and ice caps).

The most appropriate method of assessment of thermal expansion of the ocean is the use of AOGCM models (Atmosphere-Ocean General Circulation Model). Over the last 100 years the average growth trend in sea level due to thermal expansion was approximately from 0.3 to $0.7 \mathrm{~mm} / \mathrm{yr}$ (Church et al., 2001).

Observations of mass balance and calculations based on temperature changes show a decrease in the mass of glaciers and ice sheets. As a result, the contribution to the rise in global mean sea level over the last century is from 0.2 to $0.4 \mathrm{~mm} / \mathrm{yr}$ (Church et al., 2001).

Less significant are the effects of salinity changes in the volume of the reservoirs, evaporation, irrigation, and other factors. For example, Antonov et al., 2002 investigated that the global average change in salinity contributes $0.05 \mathrm{~mm} / \mathrm{yr}$ to the sea level rise for the past 50 years.

After identifying all of the factors due to which there is a change in sea level, the classification of the factors has been performed. local.

Thus, according to the scale (scene) they can be divided into global, regional and

According to the duration they can be divided into short-period, long-period and secular.

Changes in sea levels, caused by the change of the gravitational field, include tides, isostasy and geoid surface change.

Another classification can be formed, dividing all factors into exogenous and endogenous.

These factors influence on the measured sea level variations. 
Figure 1 shows the change in sea level at a station Dover (United Kingdom) during the day (Fig. 1a), during March 2012 (Fig. 1b) and after installation (Fig. 1c). The source data for $2 a$ and $2 b$ is 15 -minute values of sea level. It can be seen that large oscillations with amplitude of almost $7 \mathrm{~m}$ occur even within a month. The main reason for these oscillations is the phenomenon of the tides, which is almost always observed twice per day. If to compare these graphs with sea-level change at this station from the beginning of its installation (Fig. 1c), it can be seen that the sea level although with smaller amplitude, continues to oscillate (the original data is monthly values of sea level). The reason for this is the influence of various factors described above.

Graph shows that despite oscillations, there is a long-term trend and one can assume that it reflects the movement of the earth's crust.

The question is how to determine the crustal movement using tide gauge observations: the precision with which and within what period of time it can be determined?

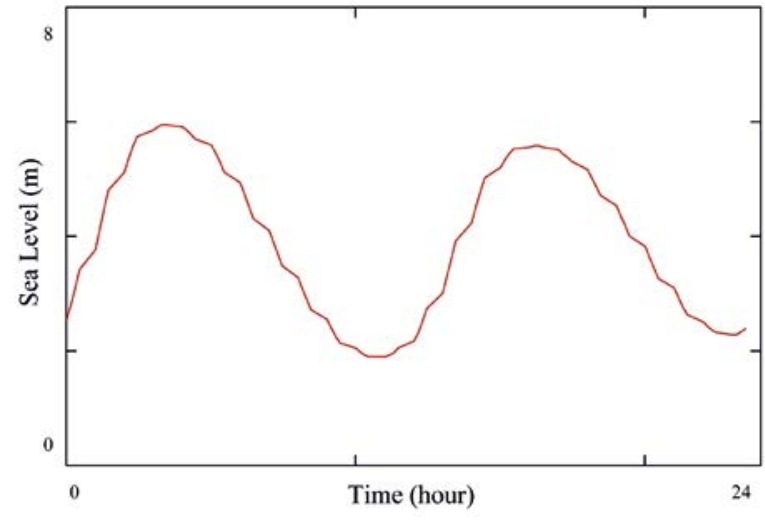

a)

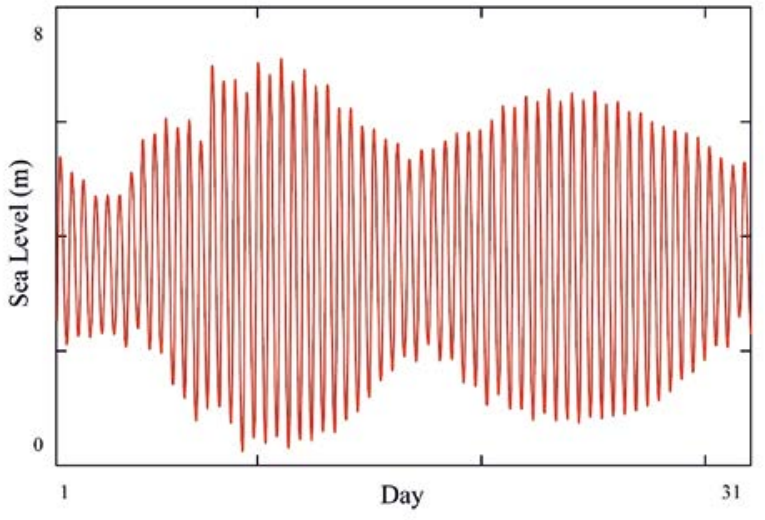

b)

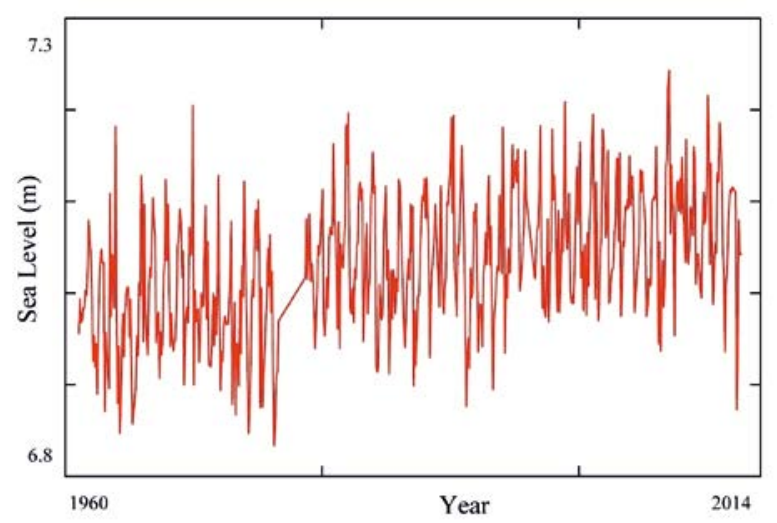

c)

Fig. 1. Sea level change at the Dover station (UK) during the day (a), during the month (b) and after the installation (c)

\subsection{The influence of the duration of tide gauge observations on the precision of determination of the vertical movements of the earth's crust}

It is clear that the longer observations are the more valuable they are for the analysis. For short periods of observations, the value of the RMS errors is higher, highlighting thereby the influence of interannual variations. Therefore, the trends (velocities) 
obtained from the short time span should not immediately be interpreted as an evidence of significant growth or descending of the sea level value.

In Pugh, 1987 you can find a prime example of how unreliable is the use of 10year trends. In addition, the authors draw attention to the importance of the choice of the initial point in the time series, which serve as a starting point for ten-year intervals.

To find the answer to the question of the precision with which we can determine the motion of the earth's crust from the tide gauge's records and how much time is needed to conduct observations in order to achieve this precision, we used the following considerations.

It is obvious that various factors affect sea level, but in most cases they are cyclical in nature (e.g., changes in atmospheric pressure varies from year to year, the tides, almost everywhere, meet twice per day, El Niño-Southern Oscillation occurs every 3-7 years and lasts from 12 to 18 months). Therefore, when averaged longperiod time series their impact is not large. The final linear component clearly reflects the behavior of the earth's crust at this coastal site. Perhaps oceanographic component will be reflected on it (like thermal expansion of the ocean due to global warming), but if it has the systematic manifestation. But if the data of the tide gauge's linear velocities will coincide with the data of the GNSS stations linear velocities that are near tide gauges, it is clearly a reason to believe that this is a movement of the earth's crust, and not the influence of the oceanographic component.

In order to conduct a research a database that contains names of European tide gauges with the coordinates of their location, duration of observations, the computed linear velocities and their precision was created. The database also contains information about GNSS stations, which are located near the respective tide gauge, namely: their names, coordinates, duration of observation, the calculated distances to the corresponding tide gauge, the calculated linear velocities and their precision.

For each countdown on the tide gauge we made an equation (1):

$$
h_{i}=-V t_{i}+a
$$

where $a$ - unknown coefficient; $V$ - unknown velocity; $h_{i}$ - countdown on the tide gauge to the epoch $t_{i}$.

Solution of the system of equations by the least squares method allows to determine the earth crust velocity $V$ and coefficient $a$. Precision $m$ of the velocity determination $V$ from time series was calculated from equation (2):

$$
m=\frac{\sum_{i=1}^{n}\left[h_{i}+V t_{i}-a\right]^{2}}{n-1},
$$

where $n$ - number of countdowns.

Data for the study of time series and selection of tide gauges was conducted using data from the following web-site http://www.psmsl.org, and GNSS stations - using data Nevada geodetic laboratory NGL (Nevada Geodetic Laboratory) web-site http://geodesy.unr.edu/index.php. Monthly and annual series of changes in mean sea level, obtained by a global network of stations, collected and published by PSMPL (Permanent Service for Mean Sea Level). Founded in 1933, PSMSL is responsible 
for the collection, publication, analysis and interpretation of sea level data from the global network of tide gauges. Geographic location of tide gauges is not homogeneous, because most of them are located in the Northern Hemisphere.

The next objective of our study was to establish the precision of the vertical velocity of the earth's surface according to tide gauges of Europe. We assumed that the precision of the vertical velocity must be an order of magnitude higher than the velocity of the tide gauge. It was determined that the average velocity of all tide gauges of Europe with taking into account the sign of movement ("+"- rising, "-" subsidence) is equal to $-0.7 \mathrm{~mm} / \mathrm{yr}$. However, the tide gauge velocity by absolute value without taking into account the direction of movement is $2.56 \mathrm{~mm} / \mathrm{yr}$. Accordingly, the tide gauge vertical velocity must be determined with an precision not worse than $0.256 \approx 0.3 \mathrm{~mm} / \mathrm{yr}$.

Figure 2 shows an example of a graphic image (and the table of numerical values) of the linear velocity change (red dots) and precision (blue dots), depending on the selected time interval for tide gauge Travemunde (Germany). The value of the linear velocity (column 1) and its precision (column 2) were obtained by "breaking" the time series into certain time periods. In columns 3 and 4 is specified time period for which the value of the trend is calculated, and column 5 shows the number of years of observations.

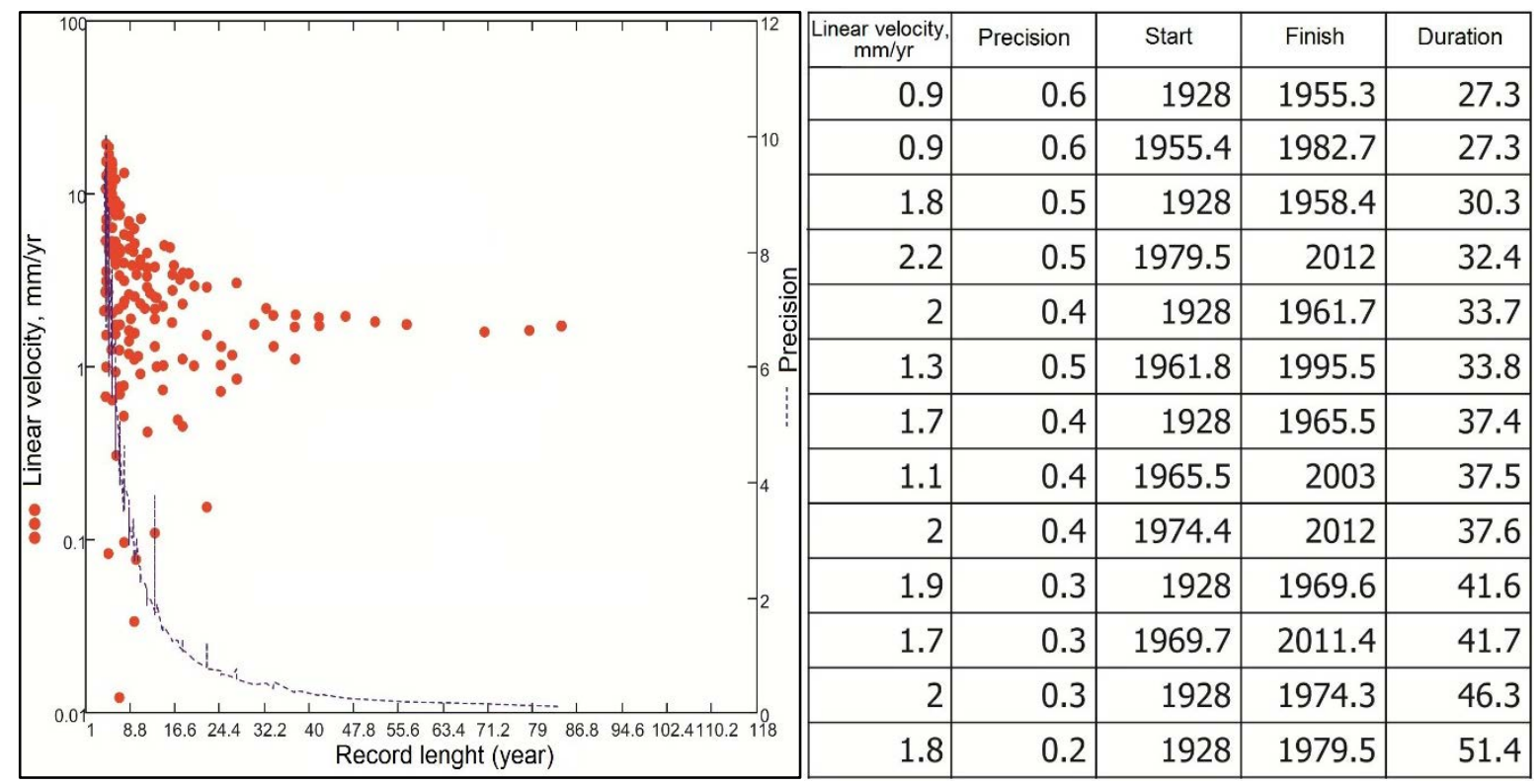

Fig.2. Graphic and numeric values of the linear velocities and their precision depending on the chosen observation period

From Figure 2 it can be seen that for short periods of observations (up to 20-30 years) significant differences in the definition of the linear velocity for the different plots of the time series are observed. But with longer observations values of the linear velocities are stabilized. Also one can see (from Fig. 2) that starting with 41.6 years of observation, the value of precision is $0.3 \mathrm{~mm} / \mathrm{yr}$. According to this scheme time sreies of all tide gauges of Europe were analyzed and for each of them the necessary length of observation was installed to achieve the precision in the linear velocity determination. The research results are presented in Table 1. 
Table 1. Desired duration of observations on the European tide gauges to achieve a given precision of $0.3 \mathrm{~mm} / \mathrm{yr}$

\begin{tabular}{|c|c|c|c|c|c|c|c|c|c|c|c|}
\hline 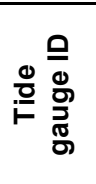 & $\begin{array}{l}\frac{2}{1} \\
\frac{1}{3} \\
0\end{array}$ & 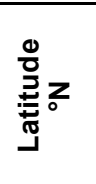 & 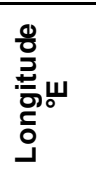 & 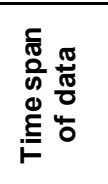 & 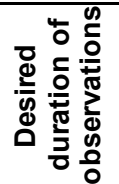 & 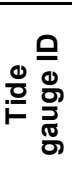 & 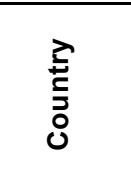 & 旁 & 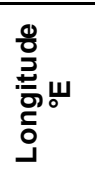 & 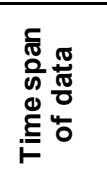 & 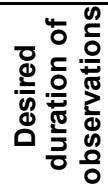 \\
\hline 486 & \multirow{15}{*}{$\begin{array}{l}\text { ते } \\
\sum_{0}^{2}\end{array}$} & 61.93 & 5.11 & $\begin{array}{c}1943- \\
2012 \\
\end{array}$ & 50 & 249 & $\begin{array}{l}\text { Aland } \\
\text { Islands }\end{array}$ & 60.03 & 20.39 & $\begin{array}{c}1924- \\
2012 \\
\end{array}$ & 62 \\
\hline 33 & & 59.68 & 10.61 & $\begin{array}{l}1954- \\
2012\end{array}$ & 53 & 2 & Poland & 53.92 & 14.23 & $\begin{array}{l}1811- \\
1999\end{array}$ & 48 \\
\hline 681 & & 68.80 & 16.55 & $\begin{array}{l}1953- \\
2012\end{array}$ & 47 & 379 & Romania & 44.17 & 28.67 & $\begin{array}{c}1933- \\
1997\end{array}$ & 45 \\
\hline 682 & & 63.11 & 7.73 & $\begin{array}{l}1953- \\
2012\end{array}$ & 53 & 42 & Ukraine & 44.62 & 33.53 & $\begin{array}{c}1945- \\
1994\end{array}$ & 45 \\
\hline 509 & & 62.47 & 6.15 & $\begin{array}{c}1951- \\
2012\end{array}$ & 53 & 638 & Iceland & 64.15 & -21.94 & $\begin{array}{c}1956- \\
2012\end{array}$ & 40 \\
\hline 562 & & 67.29 & 14.39 & $\begin{array}{l}1950- \\
2012\end{array}$ & 59 & 13 & \multirow{4}{*}{ 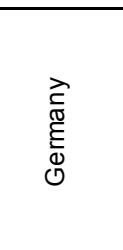 } & 53.96 & 10.87 & $\begin{array}{l}1856- \\
2012 \\
\end{array}$ & 42 \\
\hline 45 & & 68.22 & 14.48 & $\begin{array}{c}1948- \\
2012\end{array}$ & 56 & 11 & & 54.17 & 12.10 & $\begin{array}{c}1855- \\
2012\end{array}$ & 41 \\
\hline 312 & & 68.43 & 17.43 & $\begin{array}{l}1948- \\
2012\end{array}$ & 56 & 8 & & 53.90 & 11.46 & $\begin{array}{l}1849- \\
2012\end{array}$ & 41 \\
\hline 313 & & 63.43 & 9.10 & $\begin{array}{c}928- \\
2012 \\
\end{array}$ & 51 & 7 & & 53.87 & 8.72 & $\begin{array}{l}1843- \\
2010\end{array}$ & 58 \\
\hline 62 & & 59.91 & 10.74 & $\begin{array}{c}1914- \\
2012\end{array}$ & 56 & 489 & \multirow{3}{*}{ Belgium } & 51.15 & 2.73 & $\begin{array}{c}1966- \\
2012\end{array}$ & 37 \\
\hline 758 & & 70.67 & 23.68 & $\begin{array}{l}1957- \\
2012\end{array}$ & 50 & 470 & & 51.35 & 3.20 & $\begin{array}{l}1962- \\
2012 \\
\end{array}$ & 37 \\
\hline 680 & & 69.65 & 18.96 & $\begin{array}{l}1953- \\
2012\end{array}$ & 50 & 413 & & 51.23 & 2.92 & $\begin{array}{l}1943- \\
2012\end{array}$ & 37 \\
\hline 58 & & 60.40 & 5.32 & $\begin{array}{l}1915- \\
2012\end{array}$ & 46 & 1 & \multirow{2}{*}{$\begin{array}{l}0 \\
0 \\
\frac{0}{0} \\
\frac{\pi}{4}\end{array}$} & 48.38 & -4.50 & $\begin{array}{l}1807- \\
2012\end{array}$ & 39 \\
\hline 47 & & 58.97 & 5.73 & $\begin{array}{l}1919- \\
2012 \\
\end{array}$ & 45 & 61 & & 43.28 & 5.35 & $\begin{array}{l}1885- \\
2012 \\
\end{array}$ & 33 \\
\hline 302 & & 58.01 & 7.56 & $\begin{array}{c}1928- \\
2012 \\
\end{array}$ & 40 & 154 & \multirow{3}{*}{ 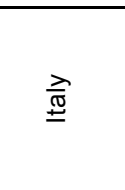 } & 45.65 & 13.76 & $\begin{array}{c}1927- \\
2012 \\
\end{array}$ & 39 \\
\hline 203 & \multirow{8}{*}{ 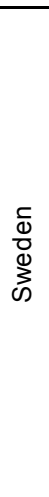 } & 64.92 & 21.23 & $\begin{array}{l}1916- \\
2012\end{array}$ & 63 & 59 & & 44.40 & 8.90 & $\begin{array}{l}1928- \\
1992\end{array}$ & 35 \\
\hline 179 & & 58.35 & 11.22 & $\begin{array}{l}1911- \\
2012\end{array}$ & 48 & 168 & & 45.43 & 12.33 & $\begin{array}{l}1909- \\
2000\end{array}$ & 39 \\
\hline 68 & & 58.74 & 17.87 & $\begin{array}{c}1887- \\
2005\end{array}$ & 59 & 353 & \multirow{2}{*}{ Croatia } & 45.30 & 14.53 & $\begin{array}{c}1953- \\
2012\end{array}$ & 37 \\
\hline 88 & & 63.99 & 20.90 & $\begin{array}{c}1892- \\
2012 \\
\end{array}$ & 63 & 352 & & 43.51 & 16.44 & $\begin{array}{c}1954- \\
2012 \\
\end{array}$ & 37 \\
\hline 78 & & 59.32 & 18.08 & $\begin{array}{l}1889- \\
2012\end{array}$ & 59 & 317 & \multirow{2}{*}{ Bulgaria } & 42.48 & 27.48 & $\begin{array}{l}1929- \\
1996\end{array}$ & 45 \\
\hline 69 & & 57.37 & 17.10 & $\begin{array}{l}1887- \\
2012\end{array}$ & 56 & 318 & & 43.18 & 27.92 & $\begin{array}{c}1929- \\
1996\end{array}$ & 45 \\
\hline 330 & & 55.52 & 12.89 & $\begin{array}{l}1930- \\
2012\end{array}$ & 46 & 432 & \multirow{2}{*}{$\begin{array}{l}\overline{0} \\
\stackrel{\mathbb{\sigma}}{0} \\
\underline{\underline{0}} \\
\underline{\underline{\underline{0}}}\end{array}$} & 53.35 & -6.22 & $\begin{array}{l}1938- \\
2009\end{array}$ & 41 \\
\hline 70 & & 56.11 & 15.59 & $\begin{array}{c}1887- \\
2012\end{array}$ & 53 & 916 & & 55.37 & -7.33 & $\begin{array}{c}1958- \\
2002\end{array}$ & 43 \\
\hline 376 & \multirow{11}{*}{ 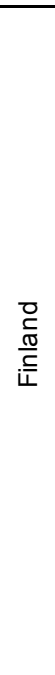 } & 61.13 & 21.43 & $\begin{array}{l}1933- \\
2011\end{array}$ & 63 & 762 & \multirow{9}{*}{ 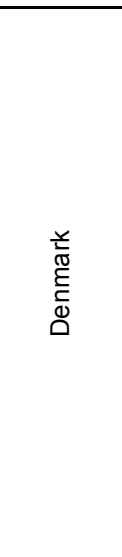 } & 54.66 & 11.35 & $\begin{array}{l}1955- \\
2012\end{array}$ & 41 \\
\hline 315 & & 60.56 & 27.18 & $\begin{array}{l}1928- \\
2011\end{array}$ & 69 & 120 & & 54.57 & 11.93 & $\begin{array}{l}1898- \\
2012\end{array}$ & 42 \\
\hline 285 & & 62.34 & 21.21 & $\begin{array}{l}1927- \\
2011\end{array}$ & 63 & 98 & & 55.29 & 10.83 & $\begin{array}{l}1896- \\
2012\end{array}$ & 37 \\
\hline 240 & & 64.67 & 24.41 & $\begin{array}{l}1923- \\
2011\end{array}$ & 69 & 81 & & 55.56 & 9.75 & $\begin{array}{l}1890- \\
2012\end{array}$ & 33 \\
\hline 239 & & 60.43 & 22.10 & $\begin{array}{c}1922- \\
2011\end{array}$ & 63 & 76 & & 56.15 & 10.22 & $\begin{array}{c}1889- \\
2012\end{array}$ & 39 \\
\hline 229 & & 65.67 & 24.52 & $\begin{array}{c}1920- \\
2011\end{array}$ & 69 & 80 & & 55.46 & 8.44 & $\begin{array}{c}1889- \\
2012\end{array}$ & 63 \\
\hline 194 & & 63.71 & 22.69 & $\begin{array}{l}1915- \\
2011\end{array}$ & 63 & 113 & & 55.33 & 11.14 & $\begin{array}{c}1897- \\
2012\end{array}$ & 38 \\
\hline 172 & & 61.59 & 21.46 & $\begin{array}{l}1911- \\
2011\end{array}$ & 63 & 119 & & 56.09 & 12.46 & $\begin{array}{l}1898- \\
2012\end{array}$ & 51 \\
\hline 71 & & 59.82 & 22.98 & $\begin{array}{l}1888- \\
1997\end{array}$ & 63 & 89 & & 57.60 & 9.96 & $\begin{array}{l}1892- \\
2012\end{array}$ & 50 \\
\hline 79 & & 65.04 & 25.42 & $\begin{array}{c}1889- \\
2011\end{array}$ & 59 & 236 & \multirow{2}{*}{ 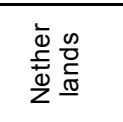 } & 53.36 & 5.22 & $\begin{array}{l}1921- \\
2012\end{array}$ & 51 \\
\hline 57 & & 63.08 & 21.57 & $\begin{array}{c}1884- \\
2011\end{array}$ & 64 & 20 & & 51.44 & 3.60 & $\begin{array}{c}1900- \\
2012\end{array}$ & 42 \\
\hline
\end{tabular}




\begin{tabular}{|c|c|c|c|c|c|}
\hline 14 & & 60.15 & 24.96 & $\begin{array}{c}1879- \\
2011\end{array}$ & 66 \\
\hline 484 & \multirow{8}{*}{$\begin{array}{l}\frac{.5}{\pi} \\
\text { के } \\
\text { D. }\end{array}$} & 43.37 & -8.40 & $\begin{array}{c}1943- \\
2012\end{array}$ & 36 \\
\hline 485 & & 43.47 & -3.80 & $\begin{array}{c}1943- \\
2012\end{array}$ & 36 \\
\hline 483 & & 42.23 & -8.73 & $\begin{array}{c}1943- \\
2012\end{array}$ & 41 \\
\hline 985 & & 36.53 & -6.28 & $\begin{array}{c}1961- \\
2012\end{array}$ & 37 \\
\hline 488 & & 36.00 & -5.60 & $\begin{array}{c}1943- \\
2012\end{array}$ & 32 \\
\hline 490 & & 36.12 & -5.43 & $\begin{array}{c}1943- \\
2002\end{array}$ & 30 \\
\hline 496 & & 36.72 & -4.42 & $\begin{array}{c}1962- \\
2012\end{array}$ & 30 \\
\hline 960 & & 38.33 & -0.48 & $\begin{array}{c}1960- \\
1997\end{array}$ & 33 \\
\hline 286 & \multirow{6}{*}{ 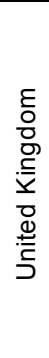 } & 53.63 & -0.19 & $\begin{array}{c}1960- \\
2011\end{array}$ & 33 \\
\hline 754 & & 52.47 & 1.75 & $\begin{array}{c}1955- \\
2012\end{array}$ & 37 \\
\hline 202 & & 50.10 & -5.54 & $\begin{array}{c}1915- \\
2012\end{array}$ & 38 \\
\hline 95 & & 55.01 & -1.44 & $\begin{array}{c}1895- \\
2012\end{array}$ & 39 \\
\hline 830 & & 60.15 & -1.14 & $\begin{array}{c}1957- \\
1999\end{array}$ & 41 \\
\hline 1109 & & 58.44 & -3.09 & $\begin{array}{c}1965- \\
2012\end{array}$ & 45 \\
\hline
\end{tabular}

\begin{tabular}{|c|c|c|c|c|c|}
\hline 24 & & 53.33 & 6.93 & $\begin{array}{c}1865- \\
2012\end{array}$ & 51 \\
\hline 25 & & 53.18 & 5.41 & $\begin{array}{c}1865- \\
2012\end{array}$ & 51 \\
\hline 23 & & 52.96 & 4.75 & $\begin{array}{c}1865- \\
2012\end{array}$ & 48 \\
\hline 22 & & 51.98 & 4.12 & $\begin{array}{c}1864- \\
2012\end{array}$ & 43 \\
\hline 9 & & 51.92 & 4.25 & $\begin{array}{c}1848- \\
2012\end{array}$ & 43 \\
\hline 32 & & 52.46 & 4.56 & $\begin{array}{c}1871- \\
2012\end{array}$ & 46 \\
\hline 1239 & \multirow{6}{*}{ Greece } & 38.84 & 20.71 & $\begin{array}{c}1969- \\
2012\end{array}$ & 41 \\
\hline 373 & & 40.63 & 22.94 & $\begin{array}{c}1969- \\
2012\end{array}$ & 37 \\
\hline 1240 & & 37.65 & 21.32 & $\begin{array}{c}1969- \\
2012\end{array}$ & 37 \\
\hline 1238 & & 40.84 & 25.88 & $\begin{array}{c}1969- \\
2012\end{array}$ & 37 \\
\hline 1233 & & 37.13 & 26.85 & $\begin{array}{c}1969- \\
2012\end{array}$ & 34 \\
\hline 1232 & & 35.49 & 24.08 & $\begin{array}{c}1969- \\
2012\end{array}$ & 43 \\
\hline
\end{tabular}

In the publication of Tsimplis and Spencer (1997) there is a similar question to the study. Analyzing data sets of the Mediterranean and the Black Sea, they noticed that 30 and 50 years of observations are required to achieve a precision of 0.5 and 0.3 $\mathrm{mm} / \mathrm{yr}$, respectively. But the authors obtained the following values having analyzed time series only from eight tide gauges. Wahl et al. (2013) investigated the change in standard error depending on the duration of observations. They showed that for the same duration of observations standard error at the tide gauge of the Netherlands and Germany is bigger that in the UK. However, the authors compared the results of observations on the same tide gauge from each country. During the study of time series Douglas (1991) conducted their update, having inputted corrections according to GIA (Glacial Isostatic Adjustment).

We have analyzed all tide gauges in Europe and have not entered any allowances to the results of observations.

Graphic image of the desired duration of observations on the European tide gauges to achieve a precision of $0.3 \mathrm{~mm} / \mathrm{yr}$ is presented in Figure 3 .

As it can be seen from the graphical representation of results, Fennoscandia, Denmark, north-western Germany and the Netherlands need more time to stabilize velocities. The least time is needed by southern Spain (tide gauge Algeciras - 30 years, tide gauge Malaga - 30 years, tide gauge Tarifa - 32 years).

In order to find out the reasons for these differences, the time series of tide gauges in Oslo (Norway) and Algeciras (Spain) should be considered (Fig. 4).

As it can be seen from the graphs, the sea level on the territory of Fennoscandia oscillates with larger amplitude than on the territory of Spain. In order to clarify and explain the reasons for these differences in results, all time series were analyzed using Fourier series. 


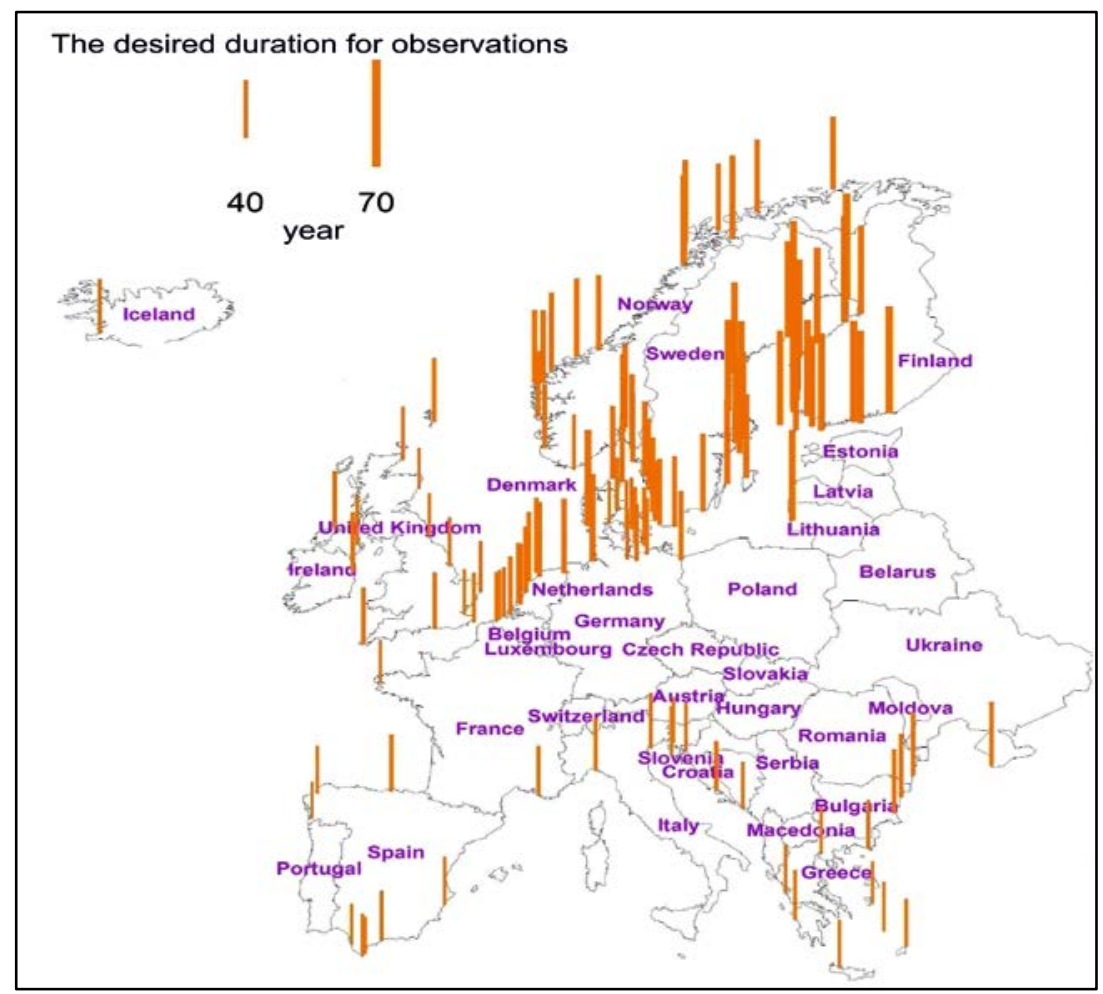

Fig.3. Graphic image of the desired duration of observations on the European tide gauges to achieve a given precision $0.3 \mathrm{~mm} / \mathrm{yr}$

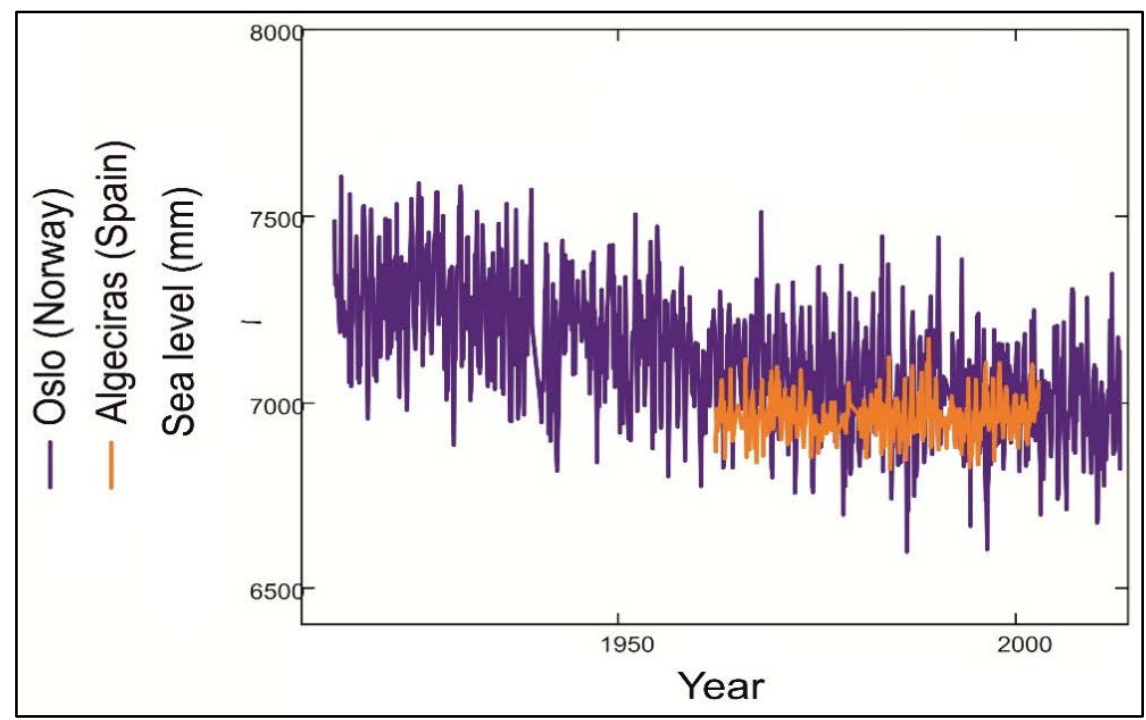

Fig. 4. Time series of tide gauges in Oslo (Norway) (purple) and Algeciras (Spain) (orange) 
Countdown on tide gauge in the time series can be described by functional dependence (3), which is the sum of the linear component and the Fourier series,

$$
\begin{gathered}
H=a_{o}+v \cdot x+\sum_{n=1}^{\infty}\left(a_{n} \cos n x+b_{n} \sin n x\right), \text { where } \\
x=\frac{t-t_{\text {start }}}{t_{\text {start }}-t_{\text {finish }}} \cdot 2 \pi,
\end{gathered}
$$

where $a_{0}, a_{n}$ and $b_{n}$ - are unknown coefficients of the Fourier series; $n$ - the number of harmonics; $t$ - epoch of observations; $v$ - vertical velocity of the tide gauge; $H$ countdown on the tide gauge to the epoch $t ; t_{\text {start }}$ - the epoch of observations start; $t_{\text {finish }}$ - the epoch of observations finish.

For every epoch of time series the appropriate equation (3) can be made. Solution of the system of equations by the least squares method allows to determine the coefficients $a_{0}, a_{n}, b_{n}$ and $v$ for the time series of any tide gauge. According to the result of these coefficients determination the approximation of all the tide gauges of Europe time series by varying number of harmonics was performed. Figure 5 shows an example of time series approximation of tide gauge in Oslo (Norway) (Fig. 5a) and Algeciras (Fig. $5 b$ ) by the harmonics of the $30^{\text {th }}$ order.

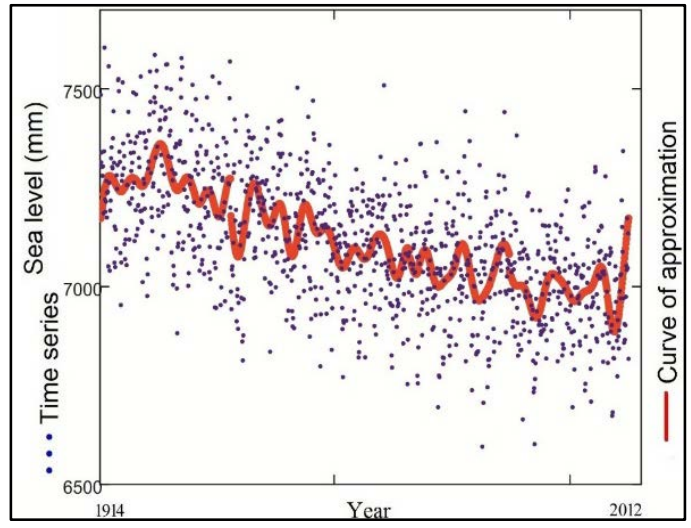

a)

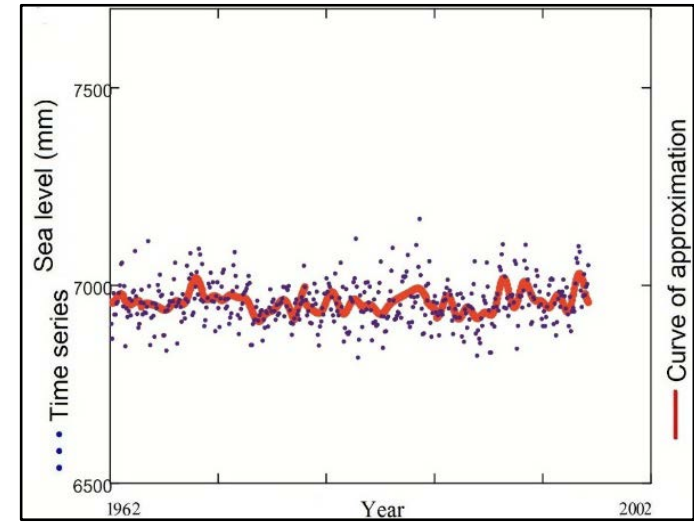

b)

Fig.5. Approximation of time series of tide gauges in Oslo (Norway) (a) and Algeciras (Spain) (b) by harmonics of the $30^{\text {th }}$ order

On the basis of this study it was determined that tide gauge of the North, Baltic and Black Seas face the largest amplitude oscillations compared to the rest of tide gauges of Europe.

To investigate these differences a linear trend $a_{0}+v \cdot x$ was removed from time series. After that all tide gauges time series were approximated by a different number of harmonics. Figure 6 shows the approximation of these time series by harmonics of the $2^{\text {nd }}, 5^{\text {th }}, 10^{\text {th }}$ to $30^{\text {th }}$ and $50^{\text {th }}$ order with removed linear trend. 


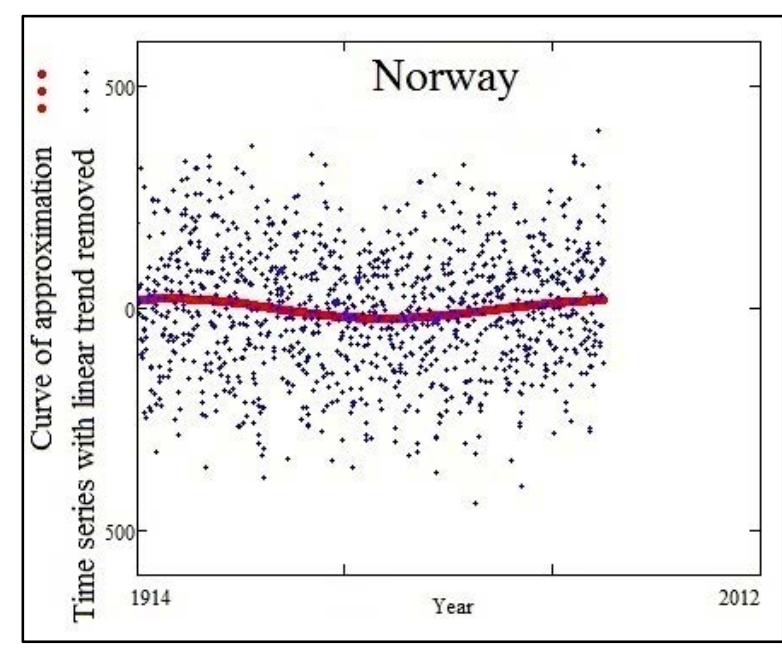

a)

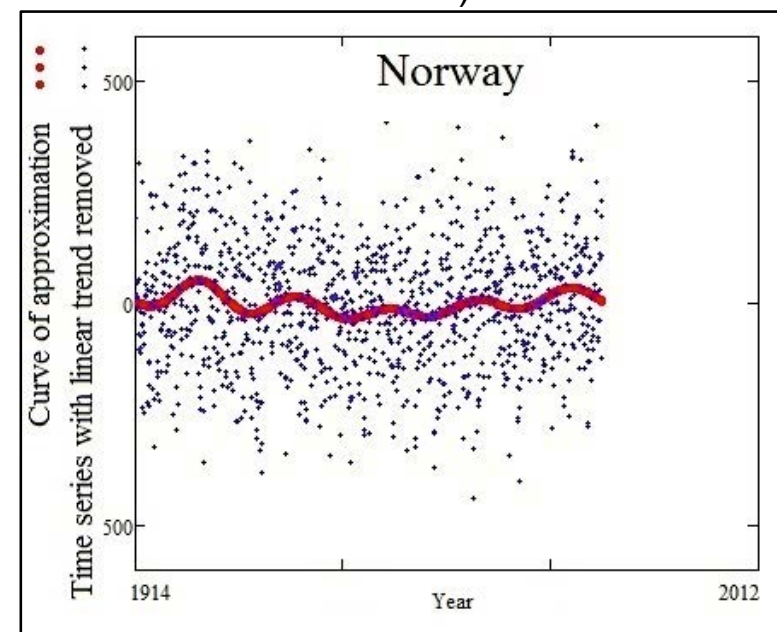

c)

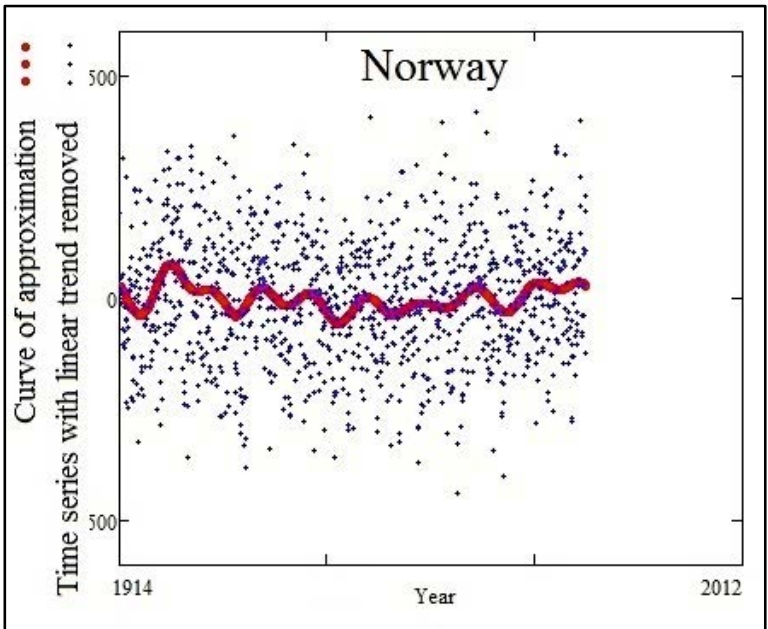

e)

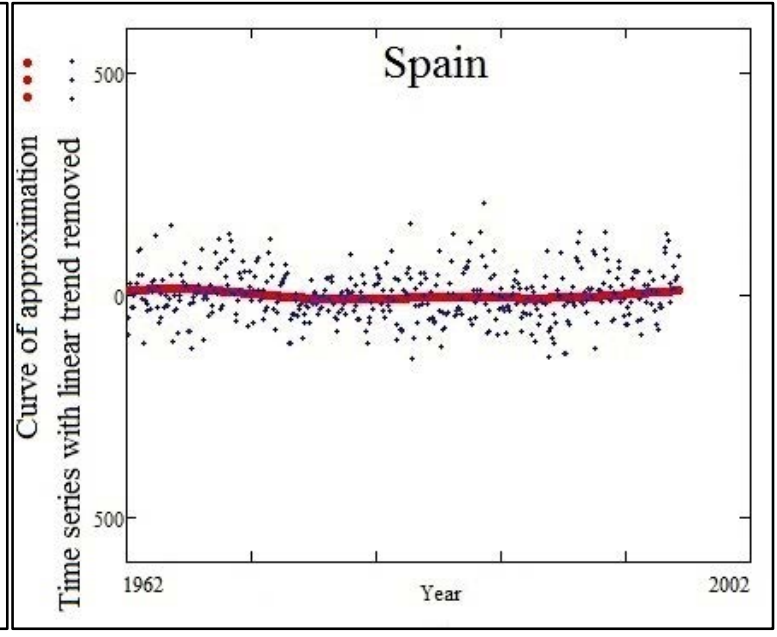

b)

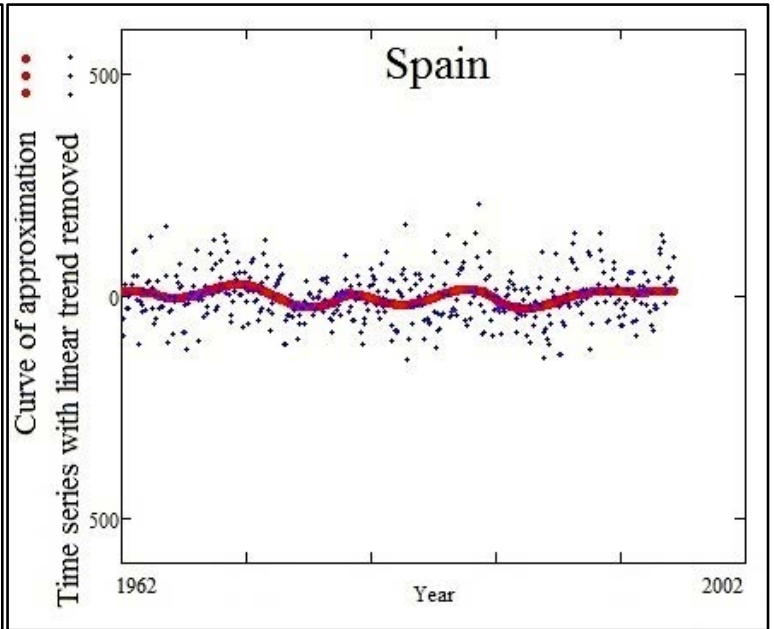

d)

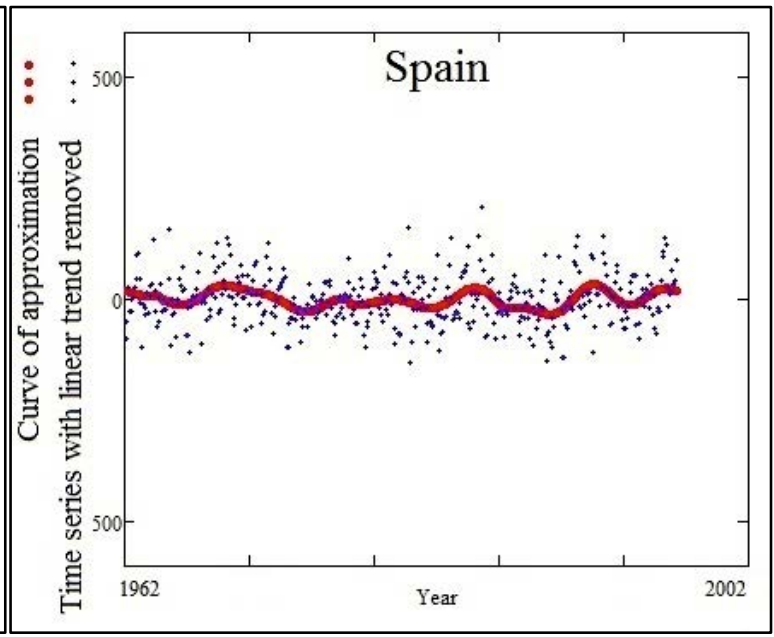

f) 


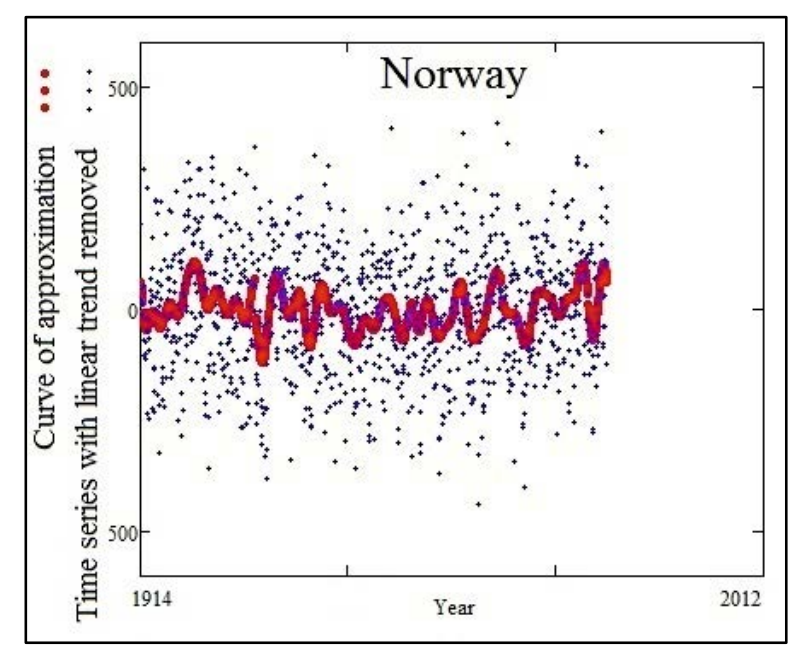

g)

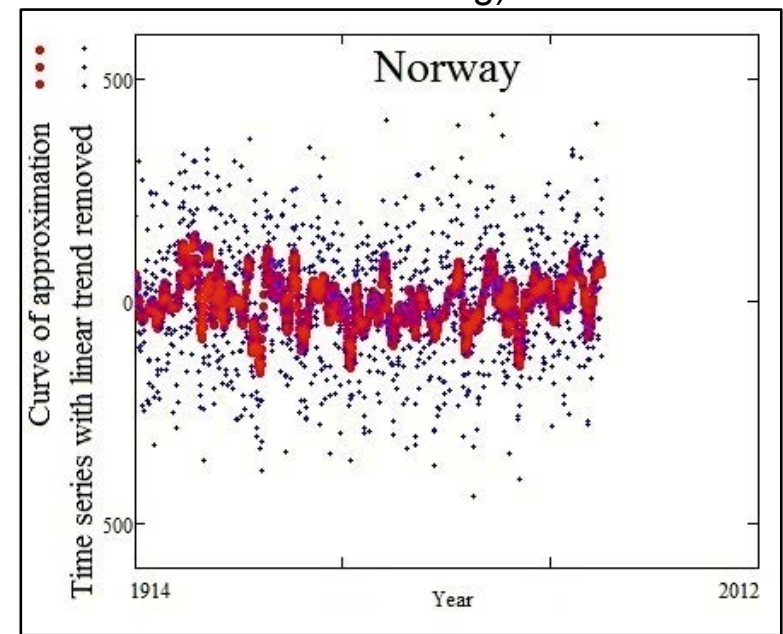

i)

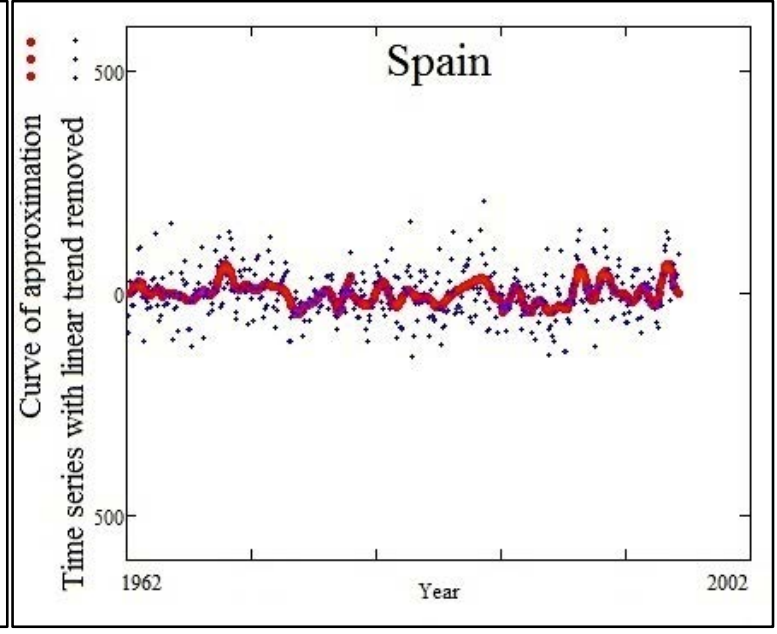

h)

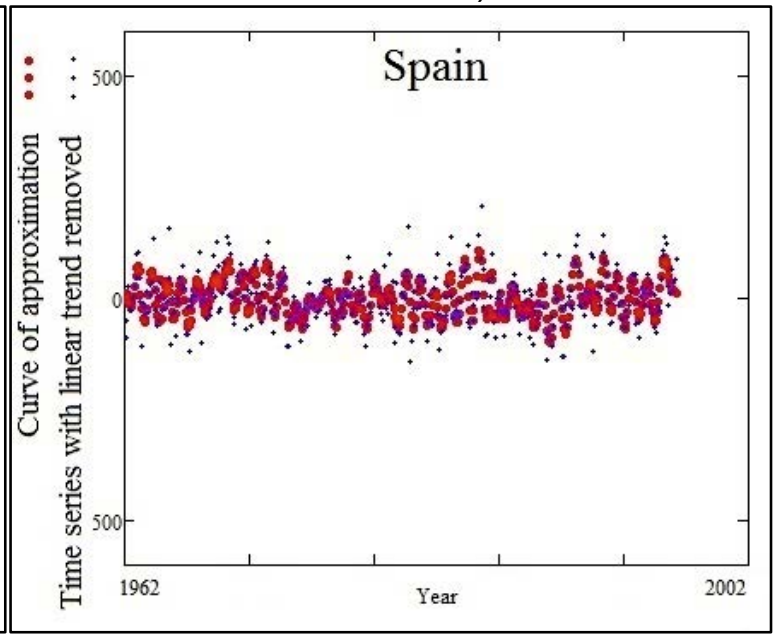

j)

Fig. 6. Approximation of time series of tide gauges in Oslo (Norway) and Algeciras (Spain) by harmonics of the $2^{\text {nd }}(\mathrm{a}, \mathrm{b}), 5^{\text {th }}(\mathrm{c}, \mathrm{d}), 10^{\text {th }}(\mathrm{e}, \mathrm{f}), 30^{\text {th }}(\mathrm{g}, \mathrm{h})$ and $50^{\text {th }}(\mathrm{i}, \mathrm{j})$ order with removed linear trend

It can be seen from the graphs that even with the approximation of the two harmonics the amplitude of oscillations on tide gauge in Oslo (Norway) is greater than on tide gauge in Algeciras (Spain). With the increase in the number of harmonics, the difference of the amplitudes between the tide gauges is growing. Table 2 shows a comparative analysis of the values of the amplitudes on these tide gauges with different number of harmonics. In addition, the period of the amplitudes is more uneven for tide gauge in Oslo (Norway).

Table 2. Comparative analysis of the values of the amplitudes on the tide gauges in Oslo (Norway) and Algeciras (Spain) with different number of harmonics

\begin{tabular}{|c|c|c|}
\hline \multirow{2}{*}{$\begin{array}{c}\text { Number } \\
\text { of harmonics }\end{array}$} & \multicolumn{2}{|c|}{ Amplitude, mm } \\
\cline { 2 - 3 } & $\begin{array}{c}\text { Oslo } \\
\text { (Norway) }\end{array}$ & $\begin{array}{c}\text { Algeciras } \\
\text { (Spain) }\end{array}$ \\
\hline 2 & 44,54 & 24,08 \\
\hline 5 & 86,80 & 53,95 \\
\hline 10 & 132,26 & 67,49 \\
\hline 30 & 227,07 & 112,60 \\
\hline 50 & 312,34 & 206,43 \\
\hline
\end{tabular}


For the territory Fennoscandia significant amplitude oscillations can be explained by the influence of GIA - the Earth's response to the retreat of the glacier that covered the earth during the last ice age. This is reflected in the constant raising of this territory, the maximum trends of which $(\sim 11 \mathrm{~mm} / \mathrm{yr})$ were observed in the Gulf of Bothnia, and trends close to 0 were observed at the edge of the former ice sheet (Milne, 2001).

Another reason for the large amplitude oscillations of the Baltic Sea level is the impact of the NAO (North Atlantic Oscillation). It is characterized by the pressure difference between the two centers of pressure anomalies, the first of which is located over Iceland (the Icelandic minimum) and the other, with the opposite sign the Canary Islands (the Azores maximum). Because the Baltic Sea is a semi-closed area, the influence of the NAO (Johansson et al., 2003, 2004) and south winds (Johansson et al., 2012) is noticeable. Studies (Zhongwei et al., 2004) have demonstrated the relationship between the NAO and sea level in the north European coast. A large part of Northern Europe has a positive correlation between increased sea levels and strong influence of the NAO, which is clearly seen in the winter. On the southwest coast of England, on the contrary, there is a negative correlation.

Wahl et al., 2013 has determined trends in sea level and their standard deviation using tide gauge observations and satellite altimetry in the North Sea. Analyzing the standard deviation obtained from two independent data sources, it was found that significant annual variations for the south-eastern part of the North Sea (Denmark, Germany, Netherlands and Belgium) were caused by exposure to westerly winds. These winds can change direction as well as its strength, becoming equatorial winds. This also can explain significant amplitude of oscillations in this region.

\section{Comparison of the results from tide gauge observations with the corresponding GNSS observations}

In the next step of our study, the results of tide gauge and GNSS observations to study the vertical movements of the earth's crust in these regions were compared. In order to do so, the database of GNSS stations, which are located close to corresponding tide gauges were observed. Namely: velocity changes of the height position of GNSS stations $V$ and the precision of their determination $m$.

For each countdown on the GNSS receiver we made an equation (4):

$$
h_{i}=V t_{i}+a
$$

where $a$ - unknown coefficient; $V$ - unknown velocity; $h_{i}$ - height, measured by GNSS reciever on the epoch $t_{i}$.

Solution of the system of equations by the least squares method allows to determine the earth crust velocity $V$ and coefficient $a$. Precision $m$ of velocity determaination $V$ from time series was calculated from equation (5):

$$
m=\frac{\sum_{i=1}^{n}\left[h_{i}-V t_{i}-a\right]^{2}}{n-1},
$$

where $n-$ number of countdowns. 
The value of the precision $m$ of the linear velocity $V$ is within $0.03 \leq m \leq 0.30 \mathrm{~mm} / \mathrm{yr}$.

If the data record of GNSS station was conducted intermittently, that is, a long time was not measured (Fig. 7a) or antenna was changed (Fig. 7b), the value of the linear velocity and its precision was calculated by the formulas (6) and (7) respectively:

$$
\begin{gathered}
V=\frac{V_{1} T_{1}+V_{2} T_{2}+\cdots+V_{n} T_{n}}{T_{1}+T_{2}+\cdots+T_{n}}, \\
m=\frac{m_{1} T_{1}+m_{2} T_{2}+\cdots+m_{n} T_{n}}{T_{1}+T_{2}+\cdots+T_{n}},
\end{gathered}
$$

where $V_{1}, V_{2}$ and $V_{n}$ - are the measurements of the linear velocities before and after the change of the antenna (or the beginning of a break in data records) calculated by relevant time periods of observations $T_{1}, T_{2} \ldots T_{n} ; m_{1}, m_{2}$ and $m_{n}$ - are the precision of relevant velocities; $T_{1}, T_{2}$ and $T_{n}$ - an appropriate period of time.

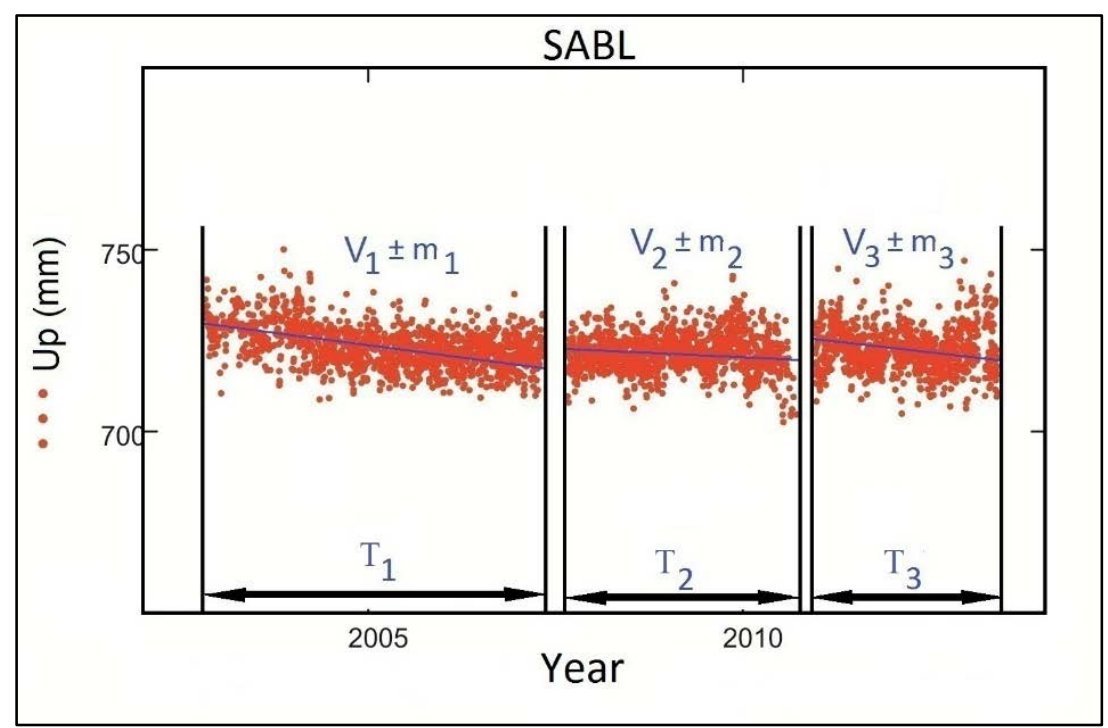

a)

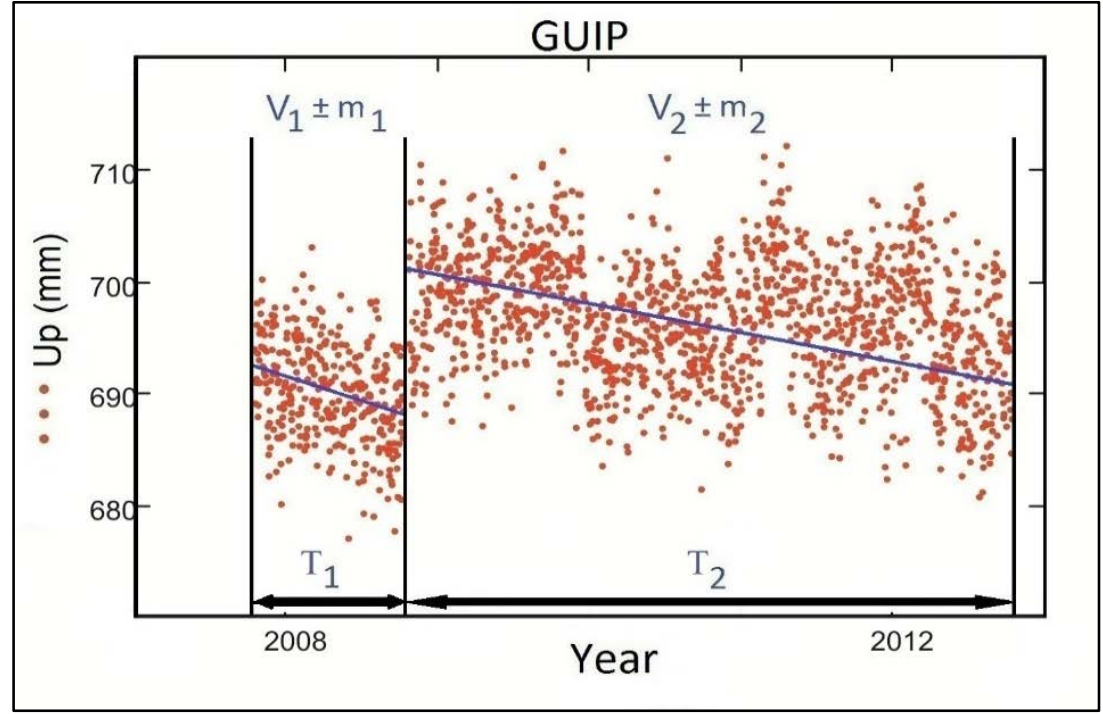

b)

Fig. 7. An example in a) breaks in the data record and b) change of GNSS station's antenna 
After this the diagram (Fig. 8) of velocity $(\mathrm{mm} / \mathrm{yr})$ of vertical movements of the European crust was built on the basis of the results tide gauge and GNSS observations.

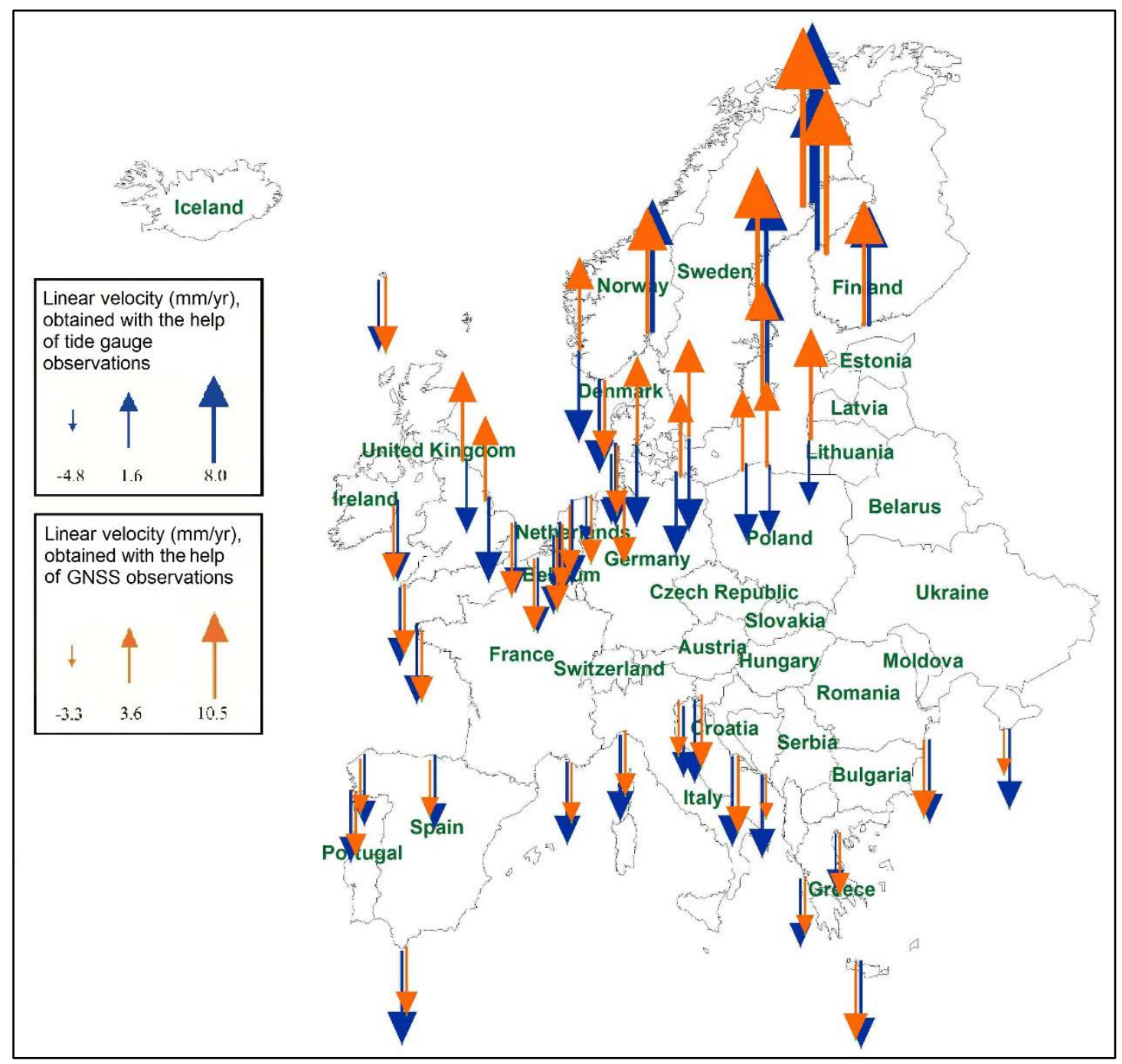

Fig 8. Diagram of velocity ( $\mathrm{mm} / \mathrm{yr}$ ) of vertical movements of the earth's crust, based on the results of tide gauge and GNSS observations

In the website www.sonel.org, the diagrams of vertical and horizontal movements of the crust of the world can be found, resulting from GNSS observations. But to build these diagrams, a small number of GNSS stations were selected. Similar can be said about the number of tide gauges that were selected for the study of trends in sea level. In this diagram, there are no tide gauges for Ukraine, Romania, and Greece. But the general scheme, which would have covered the results of both types of observations, is not there.

As you can see, results from almost entire area under study coincide. However, there are discrepancies between the results of the observations at the stations Stavanger and STAS (Norway), Klaipeda and KLPD (Lithuania), Wladyslawowo and WLAD, Ustka and REDZ (Poland), Hornbaek and BUDP, Fredericia and SMID (Denmark), Warnemunde 2 and WARN (Germany), Immingham and EASN, North Shields and NSTG (UK). The discrepancy is present even when to calculate the value of the tide gauges linear velocity over the last 30-50 years of observations. 
List of tide gauges and GNSS stations, which show differences in the results of determining the vertical movements of the crust, are shown in Table 3.

Table 3. List of tide gauges and GNSS stations, which show differences in the definitions of the vertical movements of the earth's crust

\begin{tabular}{|c|c|c|c|c|c|c|}
\hline Country & Station name & $\begin{array}{l}\text { Time span } \\
\text { of data }\end{array}$ & $\begin{array}{l}\text { Latitude } \\
{ }^{\circ} \mathrm{N}\end{array}$ & $\underset{{ }^{\circ} E}{\text { Longitude }}$ & $\begin{array}{c}\text { Linear } \\
\text { velocity, } \\
\mathrm{mm} / \mathrm{yr}\end{array}$ & $\begin{array}{c}\text { Distance, } \\
\text { km }\end{array}$ \\
\hline \multirow{2}{*}{ Norway } & Stavanger & $1919-2012$ & 58.97 & 5.73 & $-0.45 \pm 0.11$ & \multirow{2}{*}{8.94} \\
\hline & STAS & $2001-2014$ & 59.02 & 5.60 & $1.62 \pm 0.21$ & \\
\hline \multirow{2}{*}{ Lithuania } & Klaipeda & $1949-2011$ & 55.70 & 21.13 & $-3.11 \pm 0.35$ & \multirow{2}{*}{1.89} \\
\hline & KLPD & $2005-2009$ & 55.72 & 21.12 & $3.42 \pm 0.13$ & \\
\hline \multirow{4}{*}{ Poland } & Wladyslawowo & $1951-1999$ & 54.80 & 18.42 & $-2.48 \pm 0.46$ & \multirow{2}{*}{0.37} \\
\hline & WLAD & $2003-2010$ & 54.80 & 18.42 & $0.83 \pm 0.06$ & \\
\hline & Ustka & $1951-1999$ & 54.58 & 16.87 & $-1.75 \pm 0.43$ & \multirow{2}{*}{20.40} \\
\hline & REDZ & $2008-2014$ & 54.47 & 17.12 & $0.38 \pm 0.09$ & \\
\hline \multirow{4}{*}{ Denmark } & Hornbaek & $1898-2012$ & 56.09 & 12.46 & $-0.41 \pm 0.10$ & \multirow{2}{*}{39.24} \\
\hline & BUDP & $2005-2014$ & 55.74 & 12.50 & $2.15 \pm 0.21$ & \\
\hline & Fredericia & $1890-2012$ & 55.56 & 9.75 & $-1.10 \pm 0.05$ & \multirow{2}{*}{15.17} \\
\hline & SMID & $2003-2014$ & 55.64 & 9.56 & $1.04 \pm 0.16$ & \\
\hline \multirow{2}{*}{ Germany } & Warnemunde 2 & $1855-2011$ & 54.17 & 12.10 & $-1.25 \pm 0.05$ & \multirow[b]{2}{*}{0.16} \\
\hline & WARN & $2003-2014$ & 54.17 & 12.10 & $0.58 \pm 0.15$ & \\
\hline \multirow{4}{*}{$\begin{array}{l}\text { United } \\
\text { Kingdom }\end{array}$} & North Shields & $1895-2012$ & 55.01 & -1.44 & $-2.24 \pm 0.20$ & \multirow{2}{*}{0.07} \\
\hline & NSTG & $2003-2010$ & 55.01 & -1.44 & $1.28 \pm 0.07$ & \\
\hline & Immingham & $1960-2011$ & 53.63 & -0.19 & $-1.03 \pm 0.19$ & \multirow{2}{*}{20.11} \\
\hline & EASN & $2005-2010$ & 53.65 & -0.12 & $0.79 \pm 0.09$ & \\
\hline
\end{tabular}

The land on which differences in the results are observed extends within $55-60^{\circ} \mathrm{N}$ and $5^{\circ} \mathrm{W}-25^{\circ} \mathrm{E}$. The reasons for these differences require further investigation. At these stations the average RMS errors are within the definition of the values of the linear velocities. Perhaps the dominant contribution to the sea level in this region makes the oceanographic component or gravitational anomalies.

Comparing our results of vertical crustal movements determination to the results of Santamaría-Gómez et al. (2014), one can see their partial convergence. Definitely there is a rise of the crust in Norway, Sweden and Finland by the results of both methods of research. However, there are also differences in the definition of vertical crustal movements in certain areas (e.g, on tide gauges Maassluis and Vlissingen (Netherlands)).

On these tide gauges vertical land movement is smaller than the value of uncertainty $(0.26 \pm 0.5 \mathrm{~mm} / \mathrm{yr}$ on tide gauge Maassluis and $0.42 \pm 0.6 \mathrm{~mm} / \mathrm{yr}$ on tide gauge Vlissingen) according to the results of Santamaría-Gómez et al. (2014).

According to our results of research, the vertical land movement velocity on tige gauge Maassluis is: $-1.66 \pm 0.05 \mathrm{~mm} / \mathrm{yr}$ - according to the results of tide gauge observations and $-0.43 \pm 0.05 \mathrm{~mm} / \mathrm{yr}$ - according to the results of GNSS observations; on tide gauge Vlissingen: $-2.12 \pm 0.07 \mathrm{~mm} / \mathrm{yr}$ - according to the results of tide gauge observations and $-0.09 \pm 0.05 \mathrm{~mm} / \mathrm{yr}$ - according to the results of GNSS observations.

On Figure 9 results of Santamaría-Gómez et al. (2014) research (Fig. 9a) and results of our research (Fig. 9b) are depicted. Red rectangle marked area where research results do not coincide. 


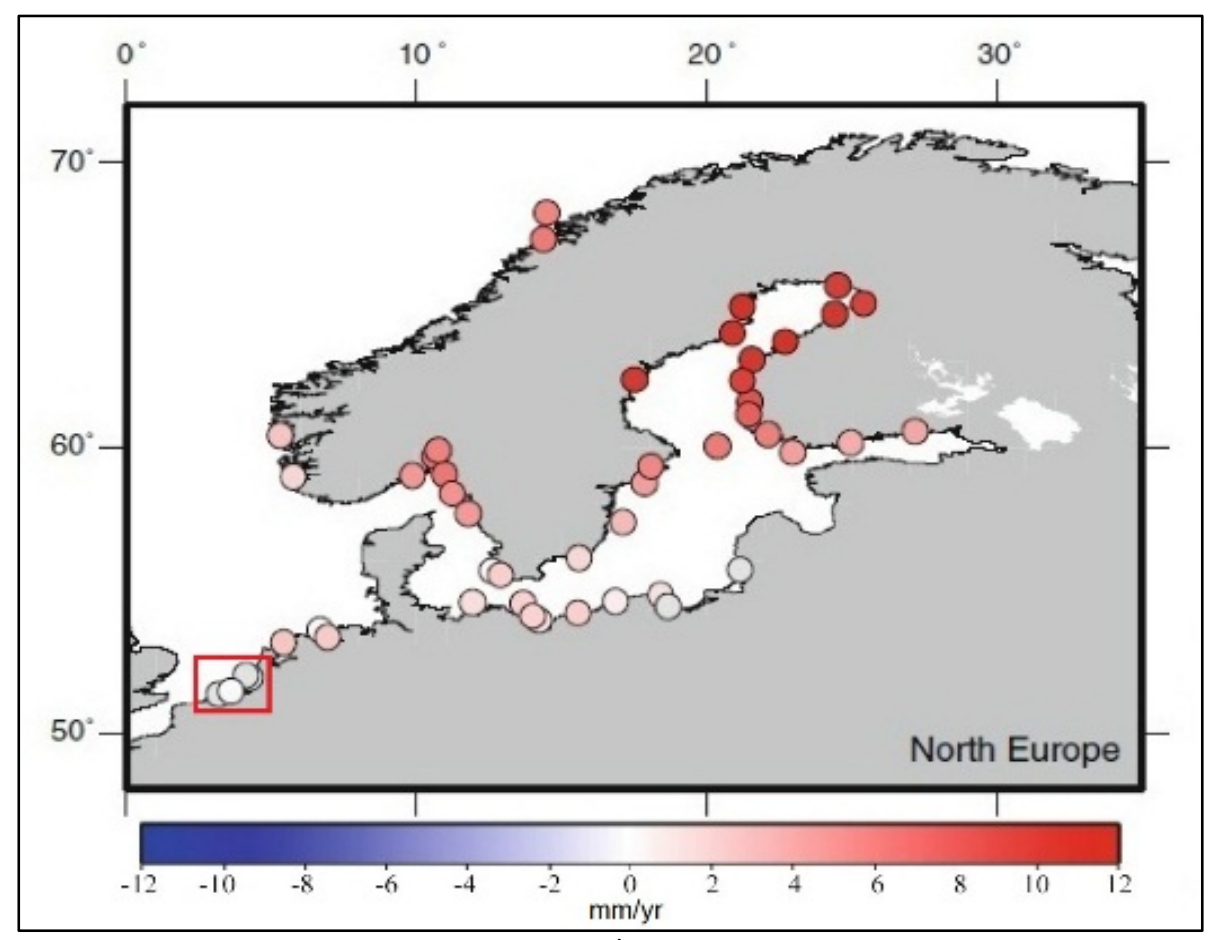

a)

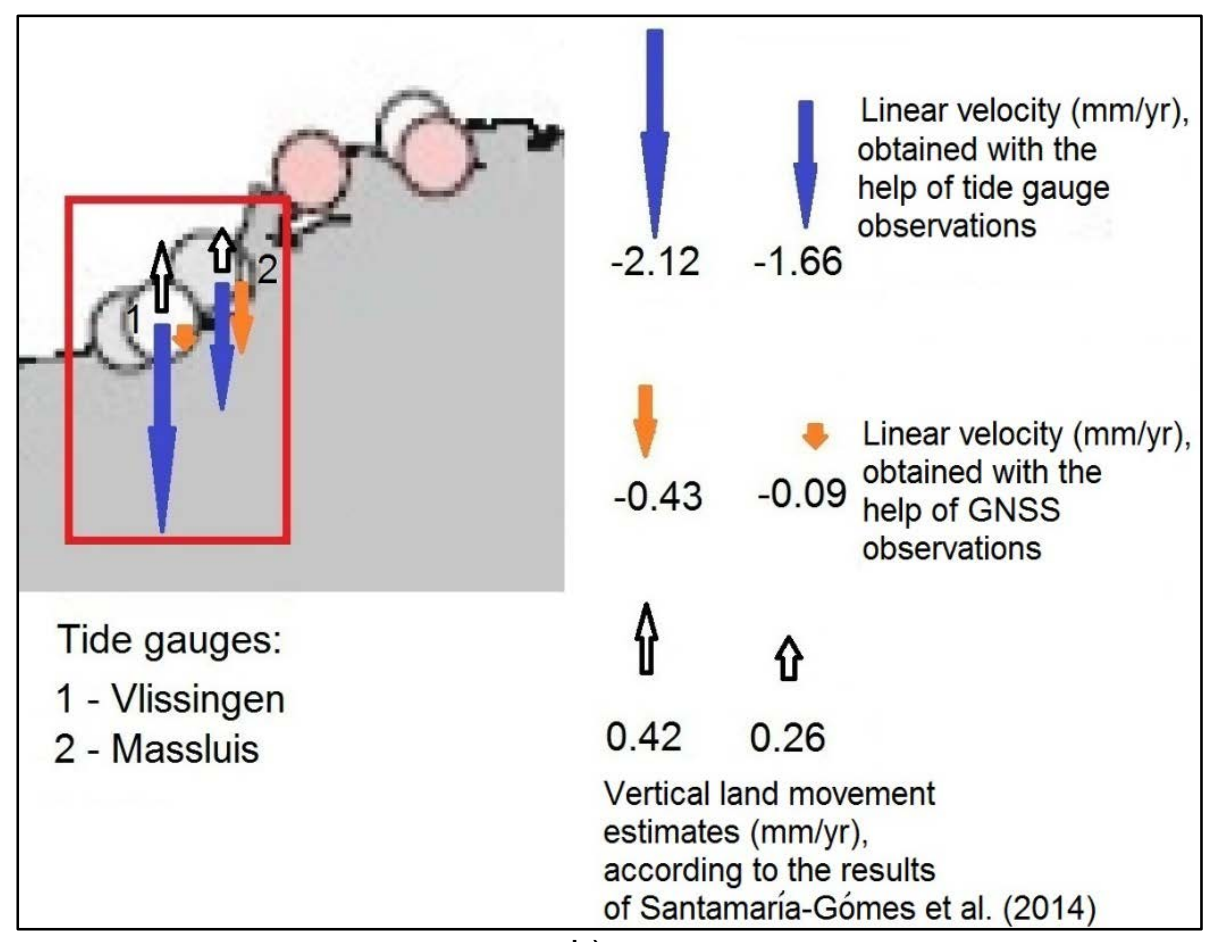

b)

Fig. 9. Results of Santamaría-Gómez et al. (2014) research (a) and results of our research (b) on area where research results do not coincide (red rectangle). 


\section{Conclusion}

The precision with which the crustal movements of the European coastline according to the results of tide gauge observations was substantiated. Its value is $0.3 \mathrm{~mm} / \mathrm{yr}$.

The necessary duration of tide gauge observations in order to achieve this precision is not the same throughout Europe. It varies depending on geographical location and oscillates between 30-69 years. For the territory Fennoscandia this duration is 40-69 years, for tide gauges, which are located in Belgium, the Netherlands, and Germany the duration is 37-58 years. The tide gauge located on the territory of Spain, needs 30-41 years of observations to achieve a precision of vertical offset determination of $0.3 \mathrm{~mm} / \mathrm{yr}$.

On the basis of harmonic analysis of time ranges of the tide gauges it was found that with increasing of oscillation amplitude the lengthening of the period of observation to achieve a given precision of vertical crust velocity determination is necessary. The reasons for long-term changes in this region are: the influence of Glacial Isostatic Adjustment (GIA) as the earth's response to the retreat of the glacier; the change in atmospheric pressure (NAO) between the two centers, one located over Iceland; the effect of the westerly winds, which can change its strength and direction, becoming equatorial.

The calculated values of the linear velocities obtained from tide gauge and GNSS observations, in most cases, coincide with each other. This may indicate that the cause of changes in sea level is rising or sinking of the earth's crust in this region.

But on the part of the east coast of the UK and on the part of the southern coast of the Baltic Sea the opposite directions of the tide gauges and GNSS stations displacement are observed. The reasons for these differences require further investigation. Perhaps the dominant contribution to the sea level in this region is made by the oceanographic component or gravitational anomalies.

\section{Acknowledgment}

This work was performed at the Department of Higher Geodesy and Astronomy Institute of Geodesy National University "Lviv Polytechnic".

\section{References}

Antonov, J. I., Levitus, S., and Boyer, T. P. (2002). Steric sea level variations during 1957-1994. J. Geophys. Res., 107(C12), 8013 - 8021. doi:10.1029/2001JC000964.

Bindoff, N. L., Willebrand, J., Artale, V., Cazenave, A., Gregory, J. M., Gulev, S. et al. (2007). Observations: oceanic climate change and sea level. IPCC Fourth Assessment Report.

Bingley, R., Dodson, A., Penna, N., Teferle, N., and Baker, T. (2001). Monitoring the vertical land movement component of changes in mean sea level using GPS: results from tide gauges in the UK. Journal of Geospatial Engineering, V. 3, No. 1, 9-20.

Bouin, M.N., Wöppelmann, G. (2010). Land motion estimates from GPS at tide gauges: a geophysical evaluation. Geophysical Journal International, 180, 193209, doi: 10.1111/j.1365-246X.2009.04411.x. 
Douglas, B.C. (1991). Global sea level rise. Journal of Geophysical Research 96 (C4), 6981-6992.

Church, J. A., et al. (2001). Changes in sea level, in Climate Change 2001: The Scientific Basis, edited by J. T. Houghton et al., 639-694, Cambridge Univ. Press, New York.

Johansson, M., Kahma, K., and Boman, H. (2003). An improved estimate for the long-term mean sea level on the Finnish coast. Geophysica, 39, 51-73.

Johansson, M., Kahma, K., Boman, H., and Launiainen, J. (2004). Scenarios for sea level on the Finnish coast. Boreal Environ. Res., 9, 153-166.

Johansson, M., Pellikka, H., Kahma K., and Ruosteenoja, K. (2012). Global sea level rise scenarios adapted to the Finnish coast. J. Mar. Syst., 129, 35-46, doi:10.1016/j.jmarsys.2012.08.007.

Kuo, C. Y., Shum, C. K., Braun, A., and Mitrovica, J. X. (2004). Vertical crustal motion determined by satellite altimetry and tide gauge data in Fennoscandia. Geophys. Res. Lett., 31, L01608, doi:10.1029/2003GL019106.

Milne, G. A, Davis, J. L., Mitrovica, J. X., Scherneck H.-G., Johansson J. M., Vermeer, M., Koivula, H. (2001). Space-geodetic constraints on glacial isostatic adjustment in Fennoscandia. Science, 291(5512), 2381- 2385.

Nerem, R.S., and Mitchum, G.T. (2002). Estimates of vertical crustal motion derived from differences of TOPEX/POSEIDON and tide gauge sea level measurements. Geophys. Res. Lett., 29(19), 1934.

Pugh, D.T. (1996). Tides, surges and mean sea-level (reprinted with corrections). Chichester, UK, John Wiley \& Sons Ltd, 486 p.

Santamaría-Gómez, A., Gravelle, M., Wöppelmann, G. (2014). Long-term vertical land motion from double-differenced tide qauqe and satellite altimetry data. Journal of Geodesy, Volume 88, Issue 3. pp. 207-222, DOI 10.1007/s00190-0130677-5.

Tsimplis, M. N., and Spencer, N. E. (1997). Collection and analysis of monthly mean sea level data in the Mediterranean and the Black Sea. J. Coastal Res., 13, 534544.

Wahl, T., Haigh, I.D., Danqendorf, S., Jensen, J. (2013). Inter-annual and lonq-term mean sea level changes along the North Sea Coastline. Journal of Coastal Research, Special Issue No. 65, 1987-1992, ISSN 0749-0208.

Zervas, C., Gill, S., and Sweet, W. (2013). Estimating Vertical Land Motion from Long-Term Tide Gauge Records. Technical Report National Ocean Service (NOS) CO-OPS 065, $22 \mathrm{p}$. 
Zhongwei, Y., Tsimplis, M.N., and Woolf, D. (2004). Analysis of the relationship between the North Atlantic oscillation and sea-level changes in northwest Europe. Int. J. Climatol. 24, 743-758. doi: 10.1002/joc.1035.

\section{Authors:}

Kornyliy Tretyak ${ }^{1}$, Prof. Dr. habil., kornel@lp.edu.ua Solomiya Dosyn ${ }^{1)}$, Ph.D. student, solomiya.dosyn@gmail.com

${ }^{1)}$ National University Lviv Polytechnic. Institute of Geodesy, 79013 Lviv, 12 Bandera street, Ukraine. 